\title{
The evidential category of mutual knowledge in Quechua
}

\author{
Daniel J. Hintz *, Diane M. Hintz 1
}

SIL International, Apartado 201, Huaraz, Ancash, Peru, South America

* Corresponding author. Tel.: 0115143396294 (Peru) and (619) 400-3921 (USA).

E-mail address: dan_hintz@sil.org.

1 E-mail address: diane_hintz@sil.org. 


\title{
The evidential category of mutual knowledge in Quechua
}

\begin{abstract}
In this paper we examine the notion of mutual knowledge, an evidential category that has remained largely unexplored in the relevant literature. Mutual knowledge principally refers to knowledge which is jointly constructed through linguistic interaction and shared perceptual experience. Sources of information for mutual knowledge include the contributions of conversational participants, together with their jointly-held beliefs and assumptions. Interlocutors use individual knowledge evidentials to introduce information and use mutual knowledge evidentials to establish facts by consensus. Once established, this shared knowledge is marked as such in subsequent speech. Evidentials are thus shown to be part of a system for building up the epistemic base shared between speakers in dynamic, interactive discourse.

In South Conchucos Quechua and in Sihuas Quechua the individual and mutual knowledge categories are formally distinguished via dedicated enclitics in paradigmatic contrast. We describe and illustrate the five-choice evidential system of South Conchucos and the six-choice system of Sihuas, then compare the two systems with each other and with the more well-known three-choice system of Cusco Quechua, a system in which mutual knowledge forms have not been attested. The comparison of the three evidential systems suggests a sequence of stages in the development of mutual knowledge as a grammatical category. The findings presented here are primarily based on spontaneous conversation, the setting in which mutual knowledge forms principally reside and in which epistemic authority is carefully negotiated.
\end{abstract}

Keywords: Evidentiality; Epistemicity; Mutual knowledge; General knowledge; Quechua; Peru

\section{Introduction}

Evidentials have been defined as grammatical markers which the speaker uses to specify an information source such as sensory perception, inference, assumption and secondhand accounts (e.g., Aikhenvald 2004). In this article we build on this notion of evidentiality as we examine the contrast between individual and mutual knowledge and present Quechua data and analysis to demonstrate that mutual knowledge is an evidential category.

Current theory and practice conditions linguists to analyze grammatical structures from the perspective of a single participant at a time. We do not quite know what to make of categories and forms which project multiple viewpoints or a single viewpoint shared by multiple participants. Such devices may seem exotic, linguistic outliers on the fringes of conventional models of grammar. On the other hand, a growing body of research develops the notion that socially shared cognition may be more central to grammar than previously supposed. According to Evans, for example, "we should not be surprised to see evidence of [multiple perspectives] being structured into the grammatical systems of various languages in a variety of ways" (2007:99). Such evidence underlies Bergqvist's description of conjunct marking in Ika, which "specifies the exclusion or inclusion of the perspective of the addressee" (2012:176). Other recent approaches to intersubjective perspective are presented by Du Bois (2007), Heritage (2012), Landaburu (2007), Nuyts (2001) and Verhagen (2005), among others.

Studies of evidential systems, as with other parts of grammar, appear to be influenced by the predisposition to consider only one participant at a time. A notable exception is the treatment of traditional or general knowledge, which instead of a single participant, involves all members of a speech community. Between these two extremes of individual knowledge on the one hand, and general knowledge on the other, lies the territory of linguistic interaction in which epistemic authority is routinely shared by the speaker, not with everyone, 
but only with addressees or other nonspeakers with whom current common ground has been established.

In the present work we position the concept of mutual knowledge within this epistemic sphere of assertion in which conversational participants linguistically monitor and build shared epistemic space. In such a view, mutual knowledge does not simply refer to information of a general nature that interlocutors assume each other to already know. Rather, it principally refers to knowledge which is jointly constructed through linguistic interaction. This "co-constructed" knowledge is tracked as conversation unfolds and is construed as such in the ensuing discourse (Clark 1996:335; Edwards 1997:114). Evidence from several Quechuan varieties can deepen our understanding of this interactional dimension of evidentiality in that a contrast between individual and mutual knowledge is formally expressed by means of dedicated enclitics.

The remainder of this article explores the concept of mutual knowledge as an evidential category. In section 2 we discuss the nature of the data and methodology. In section 3 we present an orientation to Quechua and in section 4 we briefly sketch the evidential systems in three Quechuan languages. In section 5 we contrast the notion of mutual knowledge with individual knowledge. In sections 6 and 7 we use discourse data to demonstrate how mutual knowledge is encoded in the evidential systems of South Conchucos Quechua and Sihuas Quechua, respectively. This leads to the discussion in section 8 on the relationship between mutual knowledge and general knowledge. In section 9 we step back to compare the three-, five- and six-choice evidential systems of Cusco, South Conchucos and Sihuas Quechua, and these three systems are examined from a historical point of view in section 10. Finally, in section 11 we assess the intersubjective nature of evidentiality in terms of the categories of individual and mutual knowledge.

\section{Data and methodology}

The methodology followed here assumes that a social and contextual approach is fundamental to an adequate account of the semantics and pragmatics of evidential markers. Most speech occurs in interactive discourse, whether narrating, exhorting, instructing, describing, eulogizing, and so forth. Such genres are naturally embedded in conversation and only a limited understanding of the evidential system as a whole can be discovered outside of the particular social and discourse contexts in which individual markers occur (Aikhenvald 2004:79; Cornillie 2009; Hill \& Irvine 1992:18; Maslova 2003:219; Mushin 2001:15; Nuyts 2001:396-7; among others).

Accordingly, the primary data for the study consist of spontaneous connected speech. We recorded and transcribed conversations in South Conchucos Quechua and in Sihuas Quechua with the assistance of native speakers. The consultants also provided free translations into Spanish and answered many questions as we interacted in both Quechua and Spanish about the context and subtle meaning variations. The study is not based exclusively on conversations but also includes legendary genres and reported experiences as well as contrastive elicitation.

The corpus of transcribed South Conchucos Quechua data consulted for this study consists of approximately 9,600 clauses in over five hours $(317 \mathrm{~min}$.) of recordings. It includes 37 speakers between the ages of 13 and 75 and was collected during fieldwork conducted in central Peru from 1987 to 2006. The primary data used here are two conversations comprised of 856 clauses. In the first one $(21 \mathrm{~min}$.) a brother and sister in their 20s from Huaripampa (San Marcos) discuss events of the previous week. It was recorded in 1993 in Huaraz with just the two of them present. The second conversation (11 min.) has three participants: a woman (59) and her son (25) from the town of Huari and a shepherd boy (13) from nearby Chaupi Loma. They talk about the morning's cattle-herding experience. The conversation was recorded in 2002 in their kitchen in Huari.

The corpus of transcribed Sihuas Quechua data consulted for this study consists of 667 clauses in 43 minutes of recordings collected in 2009 and 2010. The primary data used here 
are a conversation comprised of 299 clauses and several monologues comprised of 368 clauses. The conversation (13 min.) is between a man (53) from Santa Clara and his nephew (28) from Pachavilca. They talk about a recent festival and another one yet to take place. The conversation was recorded in 2010 in Huaraz. Several monologues were recorded in Huaraz by two men in their 20s from Pachavilca and two men in their 50s from Santa Clara. A personal history was recorded in a school yard in Huayllabamba (Sihuas) by a man in his 50 s from the community of Tupac Amaru.

\section{Orientation to Quechua}

The Quechua language family is native to western South America. According to the Ethnologue, 44 varieties are currently spoken by over 9 million people throughout much of the Andes and in parts of the western Amazon basin (Lewis, Simons and Fennig 2013). Torero $(1964: 446,477)$ locates the Quechua homeland along the coast and mountains of central Peru in an area roughly twice the size of Switzerland (the darkest area in Fig. 1). By far the greatest linguistic diversity is found in this Central Quechua or

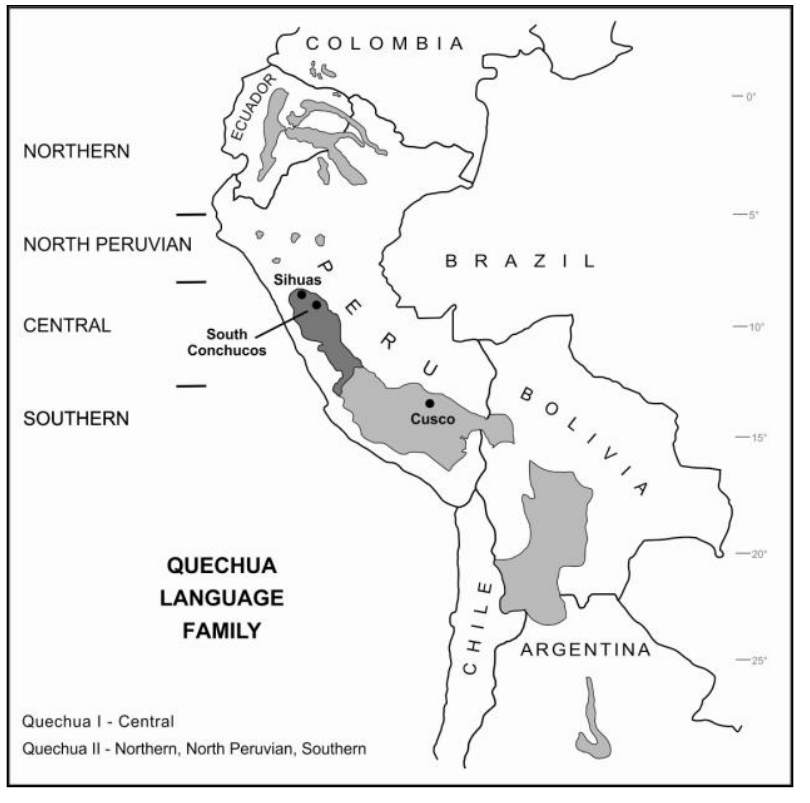

Fig. 1. MAP OF THE QUECHUA LANGUAGE FAMILY "Quechua I" region, with twenty distinct modern varieties. "Quechua II" encompasses all other varieties extending north and south of the Central Quechua homeland. Cusco (Quechua II) has $1 \frac{1}{2}$ million speakers and has been studied since the 16th century. South Conchucos (Quechua I), spoken by $1 / 4$ million people in eastern Ancash Department, has a number of recent studies. Sihuas (Quechua I) is spoken by about 6,500 people in northern Ancash and has been virtually unstudied. South Conchucos and Sihuas were chosen for intensive study due to the richness of their evidential systems. Fig. 1 is from Author1 (2011:12), modified from Landerman (1991:37).

Quechuan languages are polysynthetic and agglutinative, non-tonal and exclusively suffixing. Word order is most frequently SV and OV, with numerous instances of VS and VO motivated by pragmatic factors (Weber 1989:16; Author2 2003). A nominative-accusative system of grammatical relations is encoded by verbal suffixes and also by case-marked noun phrases, including independent pronouns. The case system distinguishes core arguments and more than a dozen obliques. The number of suffixes and enclitics ranges from 90 to over 120, depending on the language.

\section{Sketch of three Quechua evidential systems}

Quechuan languages are typically represented as having three evidential suffixes or enclitics. ${ }^{1}$ The semantics of these three markers are variously described as encoding

\footnotetext{
1 Quechua evidential morphemes freely occur on verbs, nouns, adverbs and certain particles, a characteristic of enclitics. On the other hand, these morphemes behave as suffixes in that they are prosodically integrated with the phonological word, e.g., the form can lose its final vowel closing an
} 
assertion based on direct experience $\left({ }^{*}-m i\right)$, inference/conjecture $\left({ }^{*}\right.$-chril $\left.a\right)$ and reported information ( ${ }^{*}$-shi), (e.g., Adelaar 1997; Faller 2002; Floyd 1999; Weber 1986; among others). In the Quechua II language spoken in Cusco, for example, the personal evidentials -mil- $n$ in (1a) and -chá in (1b) contrast with the nonpersonal reportative -sil-s in (1c). In the constructed examples (1)-(3) the base meaning of the verb is 'they are dancing'. ${ }^{2}$

(1) CUSCO QUECHUA — EVIDENTIALS
a. tusushanku-n
'assertion of knowledge'
b. tusushanku-chá
'conjecture'

c. tusushanku-s 'reported information'

Research among Quechua I varieties in central Peru, especially in the departments of Ancash and Huánuco, reveals more complex systems with four or more evidentials in paradigmatic contrast. ${ }^{3} \mathrm{~A}$ defining characteristic of these evidential systems is the contrast between "individual knowledge" evidentials, such as - $m i$ and -chi, and "mutual knowledge" evidentials, such as -cha: (from *-chraq) and -cher (from *-chri + affirmative *ari). In South Conchucos Quechua (Author1 2006; 2014:473-4; Author2 2007:71), this set of four interpersonal evidentials, illustrated in (2a-d), contrasts with the nonpersonal reportative -shi in $(2 \mathrm{e}) .^{4}$

(2) SOUTH CONCHUCOS QUECHUA — EVIDENTIALS
a. tushuyka:yan-mi
'assertion of individual knowledge'
b. tushuyka:yan-cha: 'confirmation/assertion of mutual knowledge'
c. tushuyka:yan-chi 'individual conjecture'
d. tushuyka:yan-cher 'mutual conjecture, appeal for consensus'

e. tushuyka:yan-shi 'reported information'

Sihuas Quechua is spoken in an area northwest of South Conchucos. This language also differentiates individual and mutual knowledge, but with a system of three contrastive pairs: - mi versus - $m a(3 a, b),-c h r i$ versus - chra $(3 \mathrm{c}, \mathrm{d})$ and -shi versus -sha $(3 \mathrm{e}, \mathrm{f})$.

erstwhile open syllable. In the present work we refer to these evidentials as enclitics, but use a hyphen in keeping with the Quechuanist tradition.

2 Examples in this work use the following alphabetic symbols in place of the corresponding IPA symbols: $\mathrm{q}$ for $\mathrm{G}, \mathrm{y}$ for $\mathrm{j}, \mathrm{r}$ for $\mathrm{r}$, ch for $\mathrm{t} \mathrm{f}$, chr for ts, sh for $\mathrm{S}$, and $1 \mathrm{l}$ for $K$.

3 Weber lists four evidentials in Huallaga Quechua: -mi, -shi, -chi and -chaq (1989:76). See also Author1 (2000:184), Parker (1976:149), and Snow (1973:113), among others. In each of these works, a modern reflex of the evidential *-chraq is glossed 'surely' and not discussed further.

${ }^{4}$ Evidentials, negatives and question markers share the same paradigmatic slot in South Conchucos Quechua. As a consequence, only one of these occurs per word, but a negative $(-t s u,-t a: k u)$ or a question marker (-ku, -ta.; -ra:) may occur on another word in the same sentence as the evidential. 
(3) SIHUAS QUECHUA — EVIDENTIALS

$\begin{array}{ll}\text { a. tushi:ka:yan-mi } & \text { 'assertion of individual knowledge' } \\ \text { b. tushi:ka:yan-ma } & \text { 'confirmation of mutual knowledge' }\end{array}$

c. tushi:ka:yan-chri 'individual conjecture'

d. tushi:ka:yan-chra 'mutual conjecture, invite discussion'

e. tushi:ka:yan-shi 'reported information'

f. tushi:ka:yan-sha 'generalized knowledge from reported information'

The evidential systems of South Conchucos and Sihuas are examined in detail in sections 6 and 7 . The structure, forms, functions and history of these two evidential systems, and also that of Cusco, are compared in sections 9 and 10.

\section{Mutual knowledge and individual knowledge}

Studies of epistemicity traditionally invoke the notion of knowledge held or expressed by an individual, whether the source of that knowledge is personal or nonpersonal, whether that knowledge results from direct or indirect experience, and whether the individual considers that knowledge to be fact or conjecture. In addition to these evidential and validational dimensions of epistemicity, the Quechua data presented here show that epistemic stance is expressed grammatically within the interactive dimension of individual versus mutual knowledge. In terms of evidentiality, the source of information for mutual knowledge has to do with the contributions of conversational participants as well as their shared nonlinguistic experiences and the beliefs and assumptions they hold in common.

Some researchers within the disciplines of philosophy and psycholinguistics have advanced our understanding of mutual knowledge from a theoretical point of view. The principles articulated by Grice, for example, show that his primary object of study is interactive discourse, a social context which depends on knowledge held in common by conversational participants. A good example is the Cooperative Principle which makes explicit reference to "the talk exchange in which you are engaged" (1975:45). More broadly, the notion of socially shared cognition has been cast in terms of "common knowledge" (Lewis 1969), "mutual knowledge" (Shiffer 1972), "common ground" (Stalnaker 1978), "common sense" (McCarthy 1990), "pragmatic intersubjectivity" (Edwards 1997) and "interaction between the speaker's territory of information and the hearer's" (Kamio 1997:23).

Beyond these foundational works, Clark and associates develop the more dynamic notion of "current common ground" (circa 1980 onward). They point out that in order to converse, shake hands, dance, what have you,

the two of them have to coordinate both the content and the process of what they are doing.... They cannot even begin to coordinate content without assuming a vast amount of shared information or common ground-that is, mutual knowledge, mutual beliefs, and mutual assumptions. And to coordinate process, they need to update their common ground moment by moment" (Clark \& Brennan 1991:127, italics added).

In our view evidential markers are essentially interactional devices for the packaging and negotiation of information in discourse. As such, language users employ these resources to coordinate content. The process-coordinating function, on the other hand, typically is not considered in research on evidential systems. As we will see in sections 6 and 7, however, evidentials in South Conchucos Quechua and in Sihuas Quechua are part of a system for coordinating both content (the epistemic base shared between speakers) and process (how they jointly build up this base). In the unfolding scenario of spontaneous everyday speech in South Conchucos, for example, conversational participants contribute 
elements of individual knowledge marked by direct $-m i$, conjectural - chi and reportative -shi. These in turn serve as "building blocks" for the evaluation and construction of mutual knowledge, which is accomplished using - cher to appeal for consensus and -cha: to confirm when warranted. This co-constructed knowledge "accumulates during the course of a conversation" (Clark \& Schaefer 1989:261). Once a proposition has been established among the participants as mutual knowledge, from that point forward it is grammatically marked as distinct from individual knowledge.

Individual knowledge and mutual knowledge are contrasted in (4) and (5). Sentence (5) with -cha: was spoken by Lucila in the South Conchucos Quechua corpus of naturallyoccurring speech; (4) is the same sentence with -mi substituted for -cha: ${ }^{5}$

(4) SOUTH CONCHUCOS QUECHUA — ASSERTION OF INDIVIDUAL KNOWLEDGE

Tsay-pa-mi qati-ya-ra-n mama-yki-kuna.

that-GEN-DIR follow-PL-PST-3 mother-2-PL

'By that route your ancestors pastured animals (I affirm).'

\section{(5) SOUTH CONCHUCOS QUECHUA — ASSERTION OF MUTUAL KNOWLEDGE}

Tsay-pa-cha: qati-ya-ra-n mama-yki-kuna.

that-GEN-MUT follow-PL-PST-3 mother-2-PL

'By that route your ancestors pastured animals (as we all know).'

In each sentence, the proposition 'by that route your ancestors pastured animals' is presented as a fact. With -mi Lucila speaks for herself alone, an assertion of individual knowledge. With -cha: she speaks for her shared knowledge community of face-to-face interactants, an assertion of mutual knowledge. With -mi the authority for the assertion rests within the speaker's deictic sphere, whereas with - cha: the deictic sphere expands to include the speaker plus her conversational participants.

\section{The South Conchucos Quechua evidential system}

We now present an analysis of the South Conchucos Quechua evidential system and use discourse data to illustrate the distinction between individual and mutual knowledge. The five evidential enclitics with their frequencies in the conversation data are $-m i 124$ (44\%), -cha: 48 (17\%), -chi 39 (14\%), - cher $54(19 \%)$ and -shi $14(5 \%)$. Due to their interactional nature, -cha: and -cher only occur in conversation. The identification of five evidentials instead of the usual

\footnotetext{
5 Abbreviations not covered by the Leipzig glossing rules (http://www.eva.mpg.de/lingua/resources/glossing-rules.php): 1=>2 = first person subject with second person object, $1 \mathrm{INCL}=$ first person inclusive, $\mathrm{AFFIRM}=$ affirmative, $\mathrm{AG}=$ agentive, $\mathrm{ALT}=$ alternative, $\mathrm{CIS}$ $=$ cislocative, action from afar, $\mathrm{CNJ}=$ conjecture evidential, elicit confirmation, CNJ.A = mutual conjecture evidential, appeal for consensus (South Conchucos), CNJ.D = mutual conjecture evidential, invite discussion (Sihuas), CONT = continuous aspect, DIR = direct evidential, individual knowledge, DIR.C = direct evidential, confirm mutual knowledge (Sihuas), DLM = delimitative, just, only, DS = adverbial, different subject, EVEN = additive, even, too, HUM = human, LIM = limitative case, MID = middle voice, MUT = assert/confirm mutual knowledge (South Conchucos), NOW = now, PFV.M = perfective, mutual consent, PRMT = purpose complement with motion verb, PST.R = recent past tense, speech-act participant if singular, PST.R3 recent past tense, third person, PUNC $=$ punctual, Q.C $=$ content question, Q.P = polar question, RPT = reportative evidential, RPT.G = reportative evidential, knowledge generalized within the social group (Sihuas), SIDE = side, SIM = similitude, $S S=$ adverbial, same subject.
} 
three attributed to Quechuan languages underscores the importance of data from everyday speech. 67

The four most frequent evidentials pattern together as a set of personal and interpersonal markers, with the speaker and interlocutors within the epistemic sphere of experience and authority. The low frequency reportative -shi, on the other hand, is nonpersonal, that is, the speaker is not within that sphere. This analysis of the South Conchucos evidential system, shown in Fig. 2, aligns with Aikhenvald's observation that for languages with "several distinct evidentiality subsystems, the reported is most likely to be set apart from others" (2004:369). It also suggests that South Conchucos is like Kashaya Pomo (de Haan 2001:203) in that inferentials (i.e., the two conjecturals -chi and -cher) pattern with direct experience evidentials, not with the reportative.

(INTER)PERSONAL

INDIVIDUAL MUTUAL

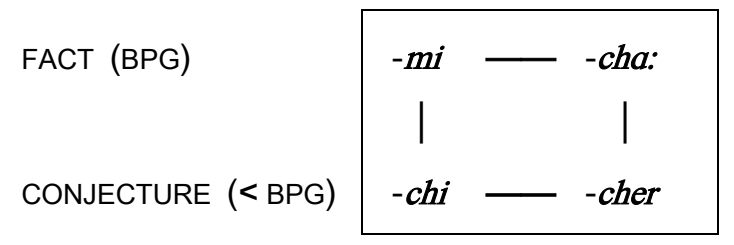

NONPERSONAL

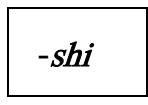

Fig. 2. THE SOUTH CONCHUCOS QUECHUA EVIDENTIAL SYSTEM

Aside from the INDIVIDUAL feature of factual - mi and conjectural -chi in South Conchucos, these two evidentials have essentially the same underlying semantics as the cognates $-m i l-n$ and -chá in Cusco Quechua. In a study of that language, Faller makes the case for the evidential concept "best possible grounds for making an assertion" (2002:130). This formulation (abbreviated BPG) accounts for the evidential value of -mi in which the speaker's evidence can range along a continuum from direct personal experience all the way to reasoning based on analogous experience. The concept of BPG can be applied to the analysis of the interpersonal division of the evidential system in South Conchucos Quechua (the large box in Fig. 2). The evidential value of -mi would be "BPG for making an assertion of individual knowledge" and that of -cha: "BPG for making an assertion of shared/mutual knowledge." This contrast of individual versus mutual knowledge is illustrated above in (4) and (5). While -mi and -cha: present the proposition as a fact, -chi and -cher present the proposition as conjecture based on reasoning or inference, i.e., the proposition is less than $100 \%$ certain (less than BPG). The four interpersonal evidentials in South Conchucos can be translated roughly as - $m i$ 'I know and you do not know' (or 'whether you know is not relevant'), -cha: 'you and I know...', -chi'I suppose...' and -cher 'you and I might suppose.... ${ }^{8}$

\footnotetext{
6 Just as certain evidentials in South Conchucos Quechua and in Sihuas Quechua only occur in conversation, several evidentials in Kashaya Pomo and sentence-final modals in Korean only occur in conversation. The studies by Oswalt (1986) and Choi (1995), respectively, would not have been possible without this type of data. These observations point to the need to build corpora which include everyday speech, "the primary setting for language use" (Clark \& Bangerter 2004:45).

7 In addition to the five evidentials discussed in this article, South Conchucos also has a very low frequency evidential -ran (presumably from ${ }^{*}-r a q$ 'yet' $+{ }^{*}-m i$ ). Like -cha: and -cher, -ran only occurs in conversation. The few examples in the corpus suggest that -ran reports individual knowledge, further specified as characterizing an extended sequence of events. This marker requires further analysis.

8 The South Conchucos dialog-only evidentials -cher and -cha: are reminiscent of Korean sentencefinal suffixes by which "shared knowledge comes to be differentiated from non-shared knowledge" (Choi 1995:198). See also "collective verification" suffixes in (Southern) Nambiquara (Kroeker 2001:64-5).
} 
A striking pattern emerges in the use of evidentials in South Conchucos Quechua conversations. Consecutive sentences may appear in a given stretch of talk with little evidential variation, but this arrangement is punctuated at intervals with clusters of evidential markers. In the primary data, 27 evidential clusters are distributed through 32 minutes of conversation, a rate of nearly one per minute. These clusters are particularly illuminating because it is here that conversational participants exploit the evidential system to coconstruct mutual knowledge.

We will now examine one of these evidential clusters to see how this works. The initial interchange between Lucila and Felix about cow behavior in (6) involves several uses of the individual knowledge marker -mi as well as sentences not formally marked with an evidential. Elías is a passive participant in the conversation until he takes a speaking turn in (6e). He is uncertain about the truth value of a proposition and uses - cher to appeal for validation and to confirm (or disconfirm) consensus. In (6f) Lucila responds positively with -cha: confirming consensus. This use of -cha: could be translated 'As we have jointly established (in the course of this conversation)'.

(6) SOUTH CONCHUCOS QUECHUA — IMMEDIATE CONTEXT, EVIDENTIAL CLUSTER

a. L: Obra:hi-man na-ski-r-qa may tantiya-ri-ya-sha-na-m.

Obraje-ALL empty.root-PFV-SS-TOP surely understand-PUNC-PL-PST-NOW-DIR 'Surely when the cows came to Obraje they realized it.'

b. F: Tsay-pita-qa qoya:-mu-shqa defrenti-na-m.

that-ABL-TOP pass.day-CIS-PST straight-NOW-DIR

'After that they came straight here.'

Tsay ura-la:-pa-pis yaqa-rka-ya:-mu-n-na.

that down-SIDE-GEN-EVEN fork-PFV.M-PL-CIS-3-NOW

'They came right down along that lower path.'

c. L: A: musya-ri-ya-n, tantiya-ri-ya-n.

yes know-PUNC-PL-3 understand-PUNC-PL-3

'Yes, they know, they understand.'

d. F: Obra:hi-pita chip kay-pa tantiya-ya-n-mi.

Obraje-ABL total this-GEN understand-PL-3-DIR

'From Obraje all the way here they understand.'

$\rightarrow$ e. E: ...Obra:hi-pita-qa reqi-ya-n-na-cher.

Obraje-ABL-TOP be.familiar-PL-3-NOW-CNJ.A

'From Obraje they are familiar it seems.'

$\rightarrow$ f. L: ...Tsay-pa-cha: peru na-pa-qa pa:sa-mu-n hallqa-pita-qa.

that-GEN-MUT but empty.root-GEN-TOP pass-CIS-3 high.grassland-ABL-TOP

'Of course, they pass along that route when they return from the high pastures.'

This interactive pattern of evidential use is common in the South Conchucos data. Direct -mi, individual conjecture -chi and mutual conjecture -cher (and less frequently reportative -shi) appear in clusters through the course of a conversation as speakers put the evidential system to work. When there is consensus, as in (6), the evidential cluster concludes with the mutual knowledge marker -cha: (21 times in our data). When there is no consensus, the conversation continues using evidentials other than -cha: (6 times in our data).

The same pattern is attested in Huamalíes, a Quechua I variety spoken immediately southeast of South Conchucos in the department of Huánuco. (7) is from a Huamalíes interview published by Howard-Malverde (1990:39). Eduardo uses direct -mi when relating his own past experience to an outsider. But when he leaves the story world (his reconstruction of local history) to address Howard-Malverde in the here and now, he 
switches to mutual knowledge -cha: In effect he is saying, 'Now this knowledge of history is established among us.'

(7) HuAMALÍES QUECHUA — IMMEDIATE CONTEXT, EVIDENTIAL CLUSTER

E: "Imanir-ta: say hirka-kuna-q uchku-ka-sh sayhoras papa:?" ni-pti-:-mi why-Q.C that mountain-PL-TOP hole-PASS-PST so.then father say-DS-1-DIR "When I asked, "Why is it that the mountains have holes in them, father?"

say ni-ma-rqa, "Inka pasa-shqa-n-mi say na:ni-n-mi," ni-r-qa, aw-mi. that say-1OBJ-PST inca pass-NMLZ-3-DIR that route-3-DIR say-SS-TOP yes-DIR he told me, "Those are the places where the Incas passed, they are their paths," he said, yes.'

H: Papa:-niki ima-nu: say-ta yachaku-rqa-n?

father-2 what-SIM that-OBJ learn-PST-3

'How did your father learn that!'

E: Unay-qa profesor-kuna ichik eskwela-chu: ka-pti-n llapan-ta-mi-r

long.ago-TOP teacher-PL small school-LOC be-DS-3 all-OBJ-DIR-AFFIRM

'In the old days when he was at school and when he asked questions

tapu-paku-yku-r tapu-paku-yku-r yachasi-shqa, say-nu:-pa.

ask-DISTR-PFV-SS ask-DISTR-PFV-SS teach-PST that-SIM-GEN

over and over again, the teachers taught him that.

$Y$ nuqa-ta papa:-ni: willa-pa:-ma-shqa-n-ta-na-mi hapa-n-lla reteni-:

and I-OBJ father-1 tell-BEN-1OBJ-NMLZ-3-OBJ-NOW-DIR only-3-DLM remember-1

And I remember everything [by myself] that my father told me

memoria-chu:, aw-mi.

memory-LOC yes-DIR

in my memory. Yes.

$\rightarrow \quad$ Say-nu:-cha: say pasa-shqa.

that-SIM-MUT that pass-PST

That's how things happened.

$\rightarrow \quad$ Say-lla-cha: $\quad$ Say-kaq kwintu-kaq usha-shqa-nsi-na-cha:; $\quad$ aw. that-DLM-MUT that-DEF story-DEF finish-PST-1INCL-NOW-MUT yes

That's how it is. Now we have finished that story, yes.'

The discourse patterns in (6) and (7)-this clustering of evidentials leading to mutual knowledge marked by -cha:-provide a rich environment for understanding -cha: as an evidential marker. In these clusters the source of information for -cha: primarily consists of the online contributions of conversational participants. Of the 48 occurrences of -cha: in the conversation data, 22 (nearly half) appear within the communicative setting of an evidential cluster, establishing mutual knowledge in the immediate context of linguistic interaction.

Occasionally, -cha: is used to frame individual knowledge as though it were in fact mutual knowledge, that is, the speaker presents information as jointly held, even though the information was not previously known by the addressee. In (8) Daniel does not know the name of a visitor and he asks for her name. Shilli responds with -cha:, in effect inviting Daniel to become an insider, to join her "mutual knowledge" community. According to a consultant, the response could have been Shilli-mi, signaling instead that the personal information is simply being supplied as requested, not freely shared as a mutual knowledge building activity. 
(8) SOUTH CONCHUCOS QUECHUA — IMMEDIATE CONTEXT, INFORMATION FRAMED AS SHARED

D: Ima-ta: huti-ki?

what-Q.C name-2

'What's your name?'

S: Shilli-cha:

Celestina-MUT

'Celestina (as we both now know).'

Mutual knowledge may be established not only through shared linguistic experience, but also through shared nonlinguistic experience. For example, the speaker and her addressees in (9) all experienced the hard rain, though they did not speak of it prior to this utterance marked with -cha: The use of -mi would be appropriate only if the speaker believed that she alone experienced the rain, in which case her claim of sole epistemic authority for the assertion would be justified. In the primary data there are three such instances of -cha: for which the source of information is shared nonlinguistic experience.

(9) SOUTH CONCHUCOS QUECHUA — IMMEDIATE CONTEXT, SHARED NONLINGUISTIC EXPERIENCE

May tamya tamya-ra-n-cha:

already rain rain-PST-3-MUT

'It surely rained hard (as we all just experienced).'

In (6)-(9) mutual knowledge marked by -cha: is established in immediate contexts. Slightly more often ( 26 of 48 times in our data) -cha: marks mutual knowledge which has been established in non-immediate contexts, i.e., prior to the present speech-act. For example, the proposition 'these animals are familiar with our house' was established as mutual knowledge and marked by -cha: in an earlier stretch of discourse. Later in the same conversation, the speaker refers to that information using -cha:, as in (10).

(10) SOUTH CONCHUCOS QUECHUA — PREVIOUSLY ESTABLISHED AMONG PARTICIPANTS

Reqi-n-cha: kay ashma-si ari wayi-ntsik-ta.

be.familiar-3-MUT this animal-EVEN yes house-1INCL-OBJ

'These animals are familiar with our house (as we previously established).'

Finally, -cha: can represent mutual knowledge that is especially well established within the larger speech community. For example, members of Andean communities in Peru are well aware that the city of Lima, referred to in (11), has millions of residents. In our conversation data there are three such instances of -cha: for which the information source is knowledge of a general nature. Mutual knowledge that is widely held has been referred to as "general knowledge" in studies of evidentials in many languages; see discussion in section 8 .

(11) SOUth Conchucos QueChUA - PREVIOUSLY ESTABLISHED, GENERALlY KNOWN

Kay marka-cho: atska-q-cha: runa-kuna ka-ya-n.

this town-LOC many-HUM-MUT person-PL be-PL-3

'In this town are many people (as everyone knows).'

Summarizing, evidential markers in South Conchucos Quechua grammatically encode individual knowledge (expressed by $-m i$ and $-c h i$ ) versus mutual knowledge (expressed by -cha: and -cher). This set of interpersonal markers further distinguish fact (-mi and -cha:) from conjecture (-chi and -cher). Speech-act participants employ these evidentials to coconstruct mutual knowledge online during conversation. Once mutual knowledge has been established, whether through linguistic interaction or shared nonlinguistic experience, it is grammatically marked as such by - cha: when addressing others who are considered to share this knowledge, that is, those who belong to the "shared knowledge" social group. Over time, 
mutual knowledge established in local contexts can become more widely diffused through the speech community. This notion of general or "generalizing" knowledge as a type of mutual knowledge is treated in section 8 .

We have argued that mutual knowledge is an evidential category and that the evidential value of -cha: is "best possible grounds for making an assertion of mutual knowledge." While individual knowledge evidentials are limited to a single mode of knowing, such as sensory perception, inference or reported information, mutual knowledge evidentials are not limited in this way due to the collective nature of this interpersonal dimension of evidentiality. Beyond these familiar information sources, mutual knowledge is acquired via shared linguistic and nonlinguistic experiences.

The discussion so far has centered on mutual knowledge expressed through the fivechoice evidential system in South Conchucos Quechua. The next section turns to the distinctive expression of mutual knowledge in the six-choice evidential system in Sihuas Quechua.

\section{The Sihuas Quechua evidential system}

The Sihuas Quechua evidential system consists of three contrastive pairs: -mi versus - $m a$, -chri versus -chra, and -shi versus -sha. The six evidential enclitics with their frequencies in the conversation data are -mi $11(12 \%),-m a 36(40 \%)$, -chri 4 (4\%), -chra 26 (29\%), -shi $10(11 \%)$ and -sha $4(4 \%)$. Due to their interactional nature, -ma, -chra and -sha occur only in the conversation data, and -chri rarely occurs outside of conversation. In contrast, the direct evidential -mi predominates in the monologue data with 53 of the 59 occurrences (90\%). These facts draw attention to the need to include both types of data in studies on evidentiality. ${ }^{9}$

An overview of the Sihuas Quechua evidential system is presented in Fig. 3. Like South Conchucos Quechua (cf. Fig. 2), Sihuas Quechua encodes a contrast between individual and mutual knowledge within the set of personal and interpersonal markers. While the contrastive pair - $m i$ versus - $m a$ presents facts, the pair -chri versus -chra presents conjectures based on inference. The functions of the Sihuas mutual knowledge markers - $m a$ and -chra are comparable, but not identical to those of their South Conchucos counterparts (-cha: and -cher). The third Sihuas Quechua contrastive pair, -shi versus -sha, distinguishes nonpersonal (secondhand) reported information from reported information that has generalized in the community. ${ }^{10}$

\footnotetext{
${ }^{9}$ Final $a$ in the Sihuas forms - $m a$, -chra and -sha probably results from the amalgamation of the three final $i$ forms plus the affirmative particle *ari (see section 10). It would be misleading to analyze $a$ as a suffix or enclitic synchronically because it is not productive and does not occur outside of these three forms. For discussion of final $a$ in other varieties of Quechua, see note 23.

10 In addition to the three pairs of evidentials discussed in this article, Sihuas Quechua also has a very low frequency evidential - chaq which is cognate with the high frequency evidential -cha: in South Conchucos (from *-chraq). This evidential does not occur in the Sihuas corpus, but the few elicited examples suggest that -chaq marks inference, based on visible evidence or reasoning. Sihuas also permits stacked evidentials, such as -misha (mirative) and -chrima (unknown outcome). These three markers require further analysis.
} 


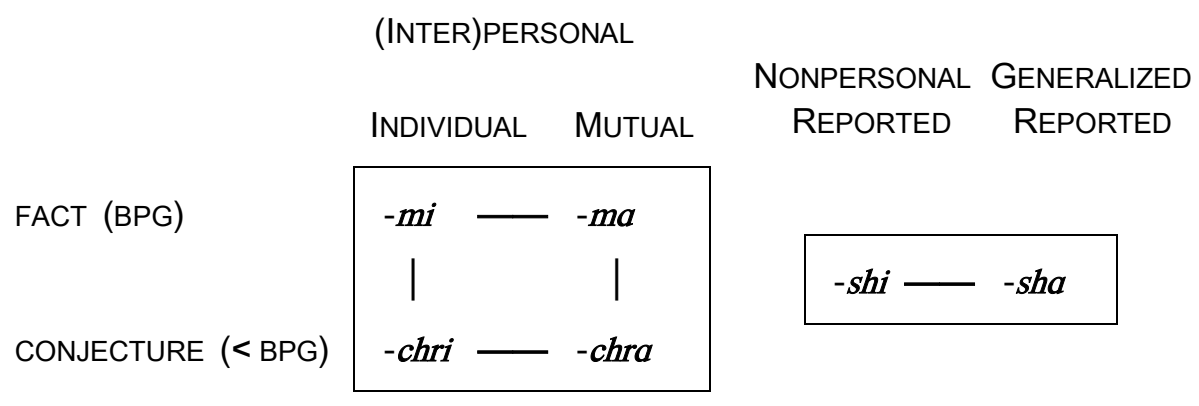

Fig. 3. THE SIHUAS QUECHUA EVIDENTIAL SYSTEM

In the (inter)personal set, -mi 'DIR' asserts 'I know...', -ma 'DIR.C' affirms 'I confirm what you just said', -chri 'CNJ' is a conjectural indicating 'I think...', while the other conjectural -chra 'CNJ.D' invites discussion, as in 'Let's think about...'. In the reportative set, -shi 'RPT' communicates 'Someone said...', while -sha 'RPT.G', the generalized reportative, conveys 'We all know because everyone is saying...'.11

In the subsequent sections we illustrate the defining features of each pair of evidential enclitics. Sihuas Quechua - $m i$, -chri and -shi have the same information sources as their cognates in Cusco Quechua and in South Conchucos Quechua, described above. The sources of evidence for their counterparts -ma, -chra and -sha are delineated below. Each example comes from the conversation text, except (13) which has a conversational quote embedded in a monologue.

\section{1. -mi 'DIR' and -ma 'DIR.C'}

Direct -mi marks assertive, often forceful statements that sometimes have the rhetorical effect of announcements. In (12) the speaker asserts that he has personally witnessed an event, and in (13) he promises to personally ensure an event will take place in the future.

(12) SiHUAS QUECHUA — INDIVIDUAL KNOWLEDGE, ASSERTION

Shamu-ra-n-mi alkaldi Julio. come-PST-3-DIR mayor Julio 'Mayor Julio came.'

(13) Sihuas Quechua — Personal commitment, Assertion 12

"Ya, ware:-mi, .. aywa-: promosyun-ta rura-q," ni-shka-.:

OK, tomorrow-DIR go-1 promotion-OBJ do-PRMT say-PST.R-1

' "OK, tomorrow I will go to do promotion," I said.'

While - mi 'DIR' marks firsthand knowledge of which the speaker is certain, i.e., individual knowledge, -ma 'DIR.C' marks knowledge that both the speaker and the addressee have acquired firsthand and of which they are certain, i.e., mutual knowledge. Each of the 36 times - $m a$ 'DIR.C' occurs in the conversation it is in response to something said previously, generally giving confirmation. When speakers use -ma with one another, they are establishing that they share that particular knowledge or experience.

\footnotetext{
11 Like Sihuas Quechua, neighboring Corongo Quechua also has the evidential enclitics - $m i$, -ma, -chri, -chra, -shi, and -(mi)sha (Author1 2000:184-7,194). These require further analysis.

12 The direct experience marker -ma 'DIR.C', unlike -mi 'DIR', is never used with the future (promises), but only with states or events in the past or the present.
} 
In (14) Edilberto confirms that Clever was dancing. He had seen Clever dance. With the use of $-m a$ he establishes that the opening night of the festival was a shared experience.

(14) SiHuAs QueCHUA — Mutual KNOWLedge, ConfIRMING RESPONSE

C: Rumpi-chro: mana-ku tushu-yka:-ya-ra-: no:-kuna-pis. Opening.night-LOC no-Q.P dance-CONT-PL-PST-1 I-PL-EVEN 'Didn't we too (exclusive) dance on the opening night of the festival?'

E: Aw-ma chay-chro:-ma tushu-yka-q-ta rika-ski-ra-q no:-pis. yes-DIR.C that-LOC-DIR.C dance-CONT-AG-OBJ see-PFV-PST-1=>2 I-EVEN 'Yes, I saw you dancing there.'

In (15) Clever is talking about how it had rained again during a soccer game at which both he and Edilberto had been present. It is understood that a lot of rain spoils a game. With the use of -ma Edilberto confirms their shared experience of the additional rain spoiling the game.

(15) SihuAs QueCHUA - Mutual KNOWLedge, ConfIRMING RESPONSE

C: Qoyat-pis tardi-yoq puklla-shka-ya-n, tamya-ra-n welta. all.day-EVEN afternoon-LIM play-PST.R-PL-3 rain-PST-3 again 'They played all day until late. It rained again (while they played).'

E: Tamya-ma mas-qa chay-chro: malogra-ku-shqa.

rain-DIR.C more-TOP that-LOC spoil-MID-PST.R3

'The additional rain spoiled things.'

In sum, -mi 'DIR' marks assertive statements of individual knowledge. -ma 'DIR.C' marks confirming responses and establishes that the speakers share the particular knowledge or experience being talked about. Information sources for -ma include the contributions of conversational participants (e.g., what Clever and Edilberto say here) as well as their shared nonlinguistic experiences (e.g., the dance in (14) and the rain in (15)).

\section{2. - chri 'CNJ' and -chra 'CNJ.D'}

Quechuan languages generally have only one conjectural evidential. The form for a given language may be -chi, -cha, -chri or -chra (Floyd 1999:94). Sihuas, like South Conchucos, is exceptional in that it has two conjectural evidentials. Both -chri 'CNJ' and -chra 'CNJ.D' pose conjectural queries in Sihuas Quechua. ${ }^{13}$

With each instance of -chri in the conversation, the speaker poses a conjectural query and gets an immediate, definitive response from the interlocutor. Usually the speech participants are already talking about the issue, when one wants confirmation from the other(s). - chri 'CNJ' marks individual conjecture, that is, the person posing the query assumes that what he thinks is right, based on a reasoned analysis of generally known facts. The use of -chri conveys: "I think $X$ to be true, but am not sure; I think you know; please tell me". In

\footnotetext{
${ }^{13}$ Neither the polar question marker (-ku) nor the content question marker (-taq) can be used in the same sentence with either of these two conjectural query markers. This contrasts with findings for the three Amerindian languages studied by Littell, Matthewson \& Peterson (2010): St'át'imcets (Lillooet Salish), NiePkepmxcín (Thompson Salish), and Gitksan (Tsimshianic). In their study of conjectural questions in these languages, a conjecture marker is used together with the polar question marker or the content question marker.
} 
each of the four occurrences in the conversation, the interlocutor responds by confirming what the speaker suggests. ${ }^{14}$

In (16) Clever suggests that a tower of fireworks (that he didn't see) went off quickly. He uses - chri to elicit confirmation, which Edilberto immediately provides.

(16) SIHUAS QUECHUA — INDIVIDUAL CONJECTURE, ELICITS CONFIRMATION

C: Sas-lla-chri.

quickly-DLM-CNJ

'Quickly'. (It burned quickly.)

E: Peru simpli-lla.

but quickly-DLM

'Very quickly.'

The conjectural evidential -chri gets an immediate, definitive response and is used only in the conversation. Language consultants provided examples in addition to those in the corpus and explained that with -chri ' $\mathrm{CNJ}$ ' the speaker wants confirmation. In contrast, conjectural queries marked by -chra 'CNJ.D' are invitations for discussion. As two or more people talk together, sometimes they come to a conclusion, but generally they cannot for lack of knowledge. In this sense, -chra marks mutual conjecture. The use of -chra could be characterized as conveying: "I'm not certain; I don't know if you know; let's talk to see if we can figure it out".

In (17) Clever communicates that it would probably be great to have two singers perform at the festival. His use of -chra conveys to Edilberto that he wants to talk about the idea. Rather than giving an immediate, definitive response (as happens when -chri is used), Edilberto responds with a pair of questions to help Clever think about it, but they do not resolve the conjecture.

(17) SIHUAS QUECHUA — MUTUAL CONJECTURE, INVITES DISCUSSION

C: Si ishkan aywa-ya-pti-n-qa-chra allish -

if two go-PL-DS-3-TOP-CNJ.D great

'If they both go, that would be great.'

E: Imano:-taq chay,

how-Q.C that

'How is that one?'

Allish-ku kanta-n?

great-Q.P sing-3

'Does she sing well?'

C: Yurisa?

Yurisa

'Yurisa?'

E: $A w$.

yes

'Yes (her).'

C: $A w$.

yes

'Yes (she sings well).'

In (18) Edilberto approaches Clever to talk about who won the soccer tournament. Clever is not certain, but responds that he believes (i.e., his assumption is that) the team

\footnotetext{
14 One of our language consultants explained that when the speaker uses -chri with more than one interlocutor, he believes that at least one of them will be able to provide confirmation.
} 
from Huayllabamba won. As they share this conjecture they go on to mention various teams that played and could possibly have won. They do not resolve the question.

(18) SIHUAS QUECHUA — MUTUAL CONJECTURE, INVITES DISCUSSION

E: Mayqan-chra gana-ra-n?

which-CNJ.D win-PST-3

'I wonder which won.'

C: Um, ... Wayllabamba-kush ima-sh.

um Huayllabamba-ALT what-RPT

'Um...Huayllabamba or someone else.' (I'm not sure)

E: A: Wayllabamba-pis shamu-ra-n no?

oh.yes Huayllabamba-EVEN come-PST-3 right

'Oh yes. Huayllabamba came too, right?'

C: A: Wayllabamba shamu-ra-n.

oh.yes Huayllabamba come-PST-3

'Yes, Huayllabamba came.

Siwas-pis shamu-ra-n.

Sihuas-EVEN come-PST-3

Sihuas came too.'

E: A: Siwas-pis um

oh.yes Sihuas-EVEN hmm

'Oh yes. Sihuas too. Hmm.'

C: Aw.. Siwas Ayhaderu,

yes Sihuas Aijadero

'Yes. Sihuas, Aijadero.' [They then mention additional teams.]

In sum, -chri 'CNJ' marks individual conjecture. It elicits immediate, definitive confirmation of a proposition the speaker thinks is probable, based on inference. Each time -chri is used in the conversation, the conjectural query posed by the speaker is resolved immediately by the interlocutor, as in (16). In contrast, -chra 'CNJ.D' marks mutual conjecture. It is used to open discussion on a matter the speaker is wondering about. The speaker and interlocutors generally are not able to resolve the conjecture, as in (17) and (18), because no one really knows. The content of a conjecture marked with -chra is based on the beliefs and assumptions of the speech-act participants, and is information of which they are both uncertain.

\section{3. -shi 'RPT' and -sha 'RPT.G'}

We now examine the two reportative evidentials -shi 'RPT' and -sha 'RPT.G'. As in other Quechuan languages, -shi marks reported information, generally with no claim of reliability, as in (19).

(19) SIHUAS QUECHUA — REPORTED INFORMATION

Chay-pita-shi mas o menos banda.

that-ABL-RPT more or less band.

'The band from there was of average quality.' (someone told me)

On the other hand, -sha marks reported information that is shared among the members of a social group. Speakers employ it to convey 'We all know this because it is customary and people are saying it.' -sha occurs four times in the conversation; it is not used in the monologue data. The source of evidence for - sha is reported information that has spread 
throughout the community. For example, in (20) Edilberto communicates that the priest celebrated mass the following day. Even though Edilberto was not present, he holds the proposition to be true because it is the customary day for mass and people were saying that it took place that day.

\section{(20) SiHUAS QUECHUA - GENERALIZED REPORTED INFORMATION \\ Warantinchika-sha selebra-shqa misa-ta chay-chro: next.day-RPT.G celebrate-PST.R3 mass-OBJ that-LOC \\ 'The following day he celebrated mass there.'}

A certain van provides regular transport service between the two communities of Pachavilca and Santa Clara. It runs with higher frequency during festivals when many people travel. Based on this collective knowledge and on the fact that many were saying it was going to come, in (21) people are certain that this van would come.

\section{(21) SIHUAS QUECHUA — GENERALIZED REPORTED INFORMATION \\ "Pachulka-pa-sha pa:sa-n" ni-ya-ra-n \\ Pachavilca-GEN-RPT.G pass-3 say-PL-PST-3 \\ ' "It (the van) will come to Pachavilca" they said.'}

(22) shows a contrast in the use of -shi and -sha across turns in the conversation. In the first two lines Clever uses -shi for something a woman had told him. Because Edilberto and others had heard what the woman said, Edilberto responds in the third line with -ma (a confirming response to Clever) and with -sha in the last line, indicating that the knowledge is shared among all who heard her.

(22) SIHUAS QUECHUA - - shi 'RPT' VERSUS - sha 'RPT.G'

C: $Y$ pay-ta-pis imbita-:;

and her-OBJ-EVEN invite-1

'And I invited her too,'

Pay-qa-shi mana pwe:di-n-ku.

she-TOP-RPT no can-3-NEG

'She can't come.' (she said to me)

E: $A w-\underline{m a}$,

yes-DIR.C

'Yes,' (as we both know)

A: mana-sha pwe:di-ya-n.

oh.yes no-RPT.G can-PL-3

'Oh yes, they can't come.' (everyone there heard her, and knew this information.)

In sum, -shi 'RPT' simply marks reported information, while -sha 'RPT.G' marks reported information that is shared among the members of a social group, information which has become generalized. A speaker makes no claim about the certainty of information marked with -shi, but interlocutors are certain of information marked with -sha due to corroborating talk by members of the social group.

\subsection{Summary of the Sihuas evidential system}

In this section we have shown how Sihuas Quechua evidential markers grammatically encode individual knowledge (expressed by -mi and -chri) versus mutual knowledge (expressed by -ma and -chra) as well as reported information (-shi) versus generalized reported information $(-s h a)$. 
In the (inter)personal set, -mi marks assertive statements of individual knowledge, while - $m a$ is used with confirming responses establishing that the speakers share the particular knowledge or experience being talked about. -chri elicits definitive confirmation on something the speaker thinks is right, based on inference, while -chra invites discussion on a conjectural matter to which neither the speaker nor the interlocutor generally have the answer. In the reportative set, -shi marks nonpersonal (secondhand) reported information, while -sha marks reported information that has generalized and is shared among the members of a social group.

Sihuas Quechua speakers effortlessly use these six evidential devices to code the source of information they are conveying, to solidify mutual understanding, and to elicit confirmation or invite discussion. These devices, often referred to by native speakers as adornments, are elegant tools for building mutual knowledge and facilitating effective communication.

\section{Mutual knowledge and general knowledge}

In previous sections we argued that mutual knowledge is an evidential category for which the information source is the interpretation of shared linguistic and nonlinguistic experience. Regardless of how mutual knowledge is acquired, whether through face-to-face interaction or other modes of socially shared cognition, once established it is marked as such (using - cha:) by any South Conchucos speaker who assumes the addressee shares this knowledge. Knowledge of a general nature which is shared by the wider speech or cultural community is also marked by - cha:, as in (11) 'In this town are many people'. This latter type of mutual knowledge has been referred to as "general knowledge", or as Edwards puts it, what members of the speech community "generally know about the world or can be expected to know" (1997:114). Here we situate general knowledge-a canonical evidential category-within the larger mutual knowledge category.

\subsection{General knowledge as a type of mutual knowledge}

Four types of general knowledge are distinguished in (23). Gnomic knowledge corresponds to information that members of the speech community assume everyone knows by virtue of some universal, intrinsic truth value. The use of -cha: for this function is most common when the speaker is a child or an adult playing with a child, as in (23a) 'This is my nose'. Encyclopedic knowledge is assumed when both the speaker and addressee have learned the same information about the outside world, as in (23b) 'There are monkeys in the jungle'. Traditional or cultural knowledge has to do with local custom, that is, information about the "inside" world, as in (23c) 'There were two yuriwa dance groups'. Each of these general knowledge types-gnomic, encyclopedic, traditional/cultural-encodes an interpretation of shared experience, an observation which aligns with our characterization of mutual knowledge. 
(23) SOUTH CONCHUCOS QUECHUA - GENERAL KNOWLEDGE TYPES
a. GNOMIC
"Sinqa-:-cha:" ni-n.
nose-1-MUT say-3
، "This is my nose" she says.'
b. ENCYCLOPEDIC
Yunka-cho:-cha: mo:nu-kuna-qa ka-n. jungle-LOC-MUT monkey-PL-TOP be-3
'There are monkeys in the jungle.'
C. TRADITIONAL
Aw ishke: ka-n-cha: yuriwa.
yes two be-3-MUT yuriwa
'Right, there were two yuriwa dance groups (as always).'
d. Generalizing
Wanu-tsi-ya-sh-cha: $\quad$ Manuel-ta-qa.
die-CAUS-PL-PST.R3-MUT Manuel-OBJ-TOP
'(The police) killed Manuel.'

General knowledge as a type of mutual knowledge is further illustrated by the notion of "generalizing" knowledge. In (23d) the first to know that the police killed Manuel were the police themselves and other witnesses. They notified the next of kin, who then informed their neighbors and friends. The news of Manuel's death gradually spread outward in ever widening circles of communication until the entire village and then neighboring villages shared this knowledge. The direct evidential -mi and reportative -shi were used with those of us who had not yet heard the news. The conjecturals - chi and -cher were used by those who could not quite believe the news at first. Once neighbors had been informed and the fact established, further mentions used the mutual knowledge evidential -cha:, as in (23d) '(The police) killed Manuel'. What began as individual knowledge became mutual knowledge through face-to-face linguistic interaction. This shared local knowledge gradually generalized as it diffused through the entire speech community.

At the local interactional level (e.g., in conversations) the social knowledge bank is fluid and the speech community constantly monitors, updates and modifies mutual knowledge. While this knowledge generalizes to some degree during the course of a conversation, only ideas that are well established or of lasting consequence become fully entrenched as general knowledge. In essence, general knowledge is a type of mutual knowledge in which information of a general nature is held in common by members of the wider speech community.

As shown in section 6, mutual knowledge -cha: in South Conchucos covers this entire range of shared knowledge situations, whether the information is specific or generic, and whether this information is jointly held by two individuals, a neighborhood or the entire speech community. From this we understand that the core semantics of -cha: centers in the notion of shared knowledge and experience, whereas the degree of specificity of the information and the scope of the shared knowledge community are matters of pragmatics. ${ }^{15}$ In this way, general knowledge represents just one type of the larger mutual knowledge category which encompasses general knowledge plus the interpersonal types of knowledge shared by people in face-to-face interaction.

\subsection{General knowledge marker selection in Quechua}

The mutual knowledge evidential -cha: can mark "encyclopedic" general knowledge in South Conchucos, as illustrated in (23b) 'There are monkeys in the jungle'. In the same context in Cusco Quechua (24), the marker of choice is the direct evidential $-m i /-n$ which conveys

\footnotetext{
15 The gradient relationship between mutual and general knowledge is analogous to that between habitual and generic aspect which "lies in the specificity of the participants" (Author1 2011:79; see also Chafe 1970:168-78).
} 
"knowledge that is taken for granted within a culture, and knowledge that is typically taught in school or found in encyclopedias" (Faller 2002:133). South Conchucos speakers indicate that the use of -mi in (23b) would not communicate general knowledge as in Cusco (24), but would specify the exclusion of the perspective of the addressee and confer expert status on the speaker.

\section{(24) CUSCO QUECHUA — ENCYCLOPEDIC KNOWLEDGE \\ Yunka-pi-n k'usillu-kuna-qa ka-n. \\ jungle-LOC-DIR monkey-PL-TOP be-3 \\ 'There are monkeys in the jungle.'}

In the absence of a dedicated general knowledge marker, language users select the form which provides the closest fit. South Conchucos speakers select the mutual knowledge evidential -cha: which provides a very close semantic match. Of the three evidentials available in Cusco, the direct evidential $-m i-n$ is selected over the reportative and the conjectural. The three evidentials in Pastaza Quichua of Ecuador are cognate with those in Cusco. However, it is not the direct evidential $-m i$ which is recruited for the general knowledge function, but reportative -shi which can "express conventional wisdom or generally accepted knowledge" (Nuckolls 2008:83). ${ }^{16}$ Similarly, as presented in section 7.3, Sihuas Quechua speakers select the generalized reported knowledge evidential -sha (but not the simple reportative -shi) to mark generally accepted knowledge which has been passed from one person to another.

The Quechua forms recruited to convey general knowledge are summarized in Table 1. The fact that four members of the same language family, each with a highly developed set of evidentials, select four different non-dedicated forms to represent generally known facts suggests that a general knowledge marker may be the last to attain grammatical status within an evidential system. Late stages in the development of Quechua evidential systems are examined in section 10 .

Table 1. QUECHUA EVIDENTIAL MARKERS RECRUITED FOR GENERAL KNOWLEDGE

\begin{tabular}{|c|c|c|c|}
\hline QUECHUA LANGUAGE & FORM & REGION & REFERENCE \\
\hline Cusco & $-m i \quad$ 'DIR' & Southern & Faller 2002:133 \\
\hline Pastaza & -shi 'RPT' & Northern & Nuckolls 2008:83 \\
\hline South Conchucos & -cha: 'MUT' & Central & Author1 2006 \\
\hline Sihuas & -sha 'RPT.G' & Central & this article, section 7.3 \\
\hline
\end{tabular}

\subsection{General knowledge versus inference based on general knowledge}

While Quechuan languages use the evidential of nearest equivalence to report general knowledge, some languages have a dedicated form for that function. For example, the highly elaborated evidential system in Central Pomo includes the general knowledge enclitic $=$ ?ma, as in "chémul=?ma 'it rained' (That's an established fact.)" (Mithun 1999:181). In Mamaindê, "the general knowledge evidential /niñta/ is used for information that any adult native member of the community would know" (Eberhard 2009:463).

Note that general knowledge (marked as a fact) is fundamentally different from inference based on general knowledge or assumption (marked as an inference). As an example of the latter, consider the Tsafiki nominalizer plus verb class marker combination - $n-k i$ in "Manuel ano fi-n-ki-e 'Manuel must have eaten' (He always eats at 8:00;

\footnotetext{
${ }^{16}$ As in Pastaza Quichua, reportatives in Tariana and Shipibo-Konibo "are used to describe traditional knowledge" (Aikhenvald 2003:18).
} 
it's now 9:00.)" Dickinson refers to this evidential category as "inference from general knowledge" (2000:407-8). This category is similarly illustrated by the Tariana suffix -sika in "phimaka-kade-sika diha 'it is (therefore) not cooked (INFERRED GENERIC)" (Aikhenvald 2003:139). Such forms do not mark general knowledge per se, that is, facts of a general nature shared by the wider speech community, but rather, deductions on the part of individual speakers regarding a specific situation. As a rule, general knowledge (fact) patterns with DIRECT/VISUAL evidentials, whereas inferences and assumptions based on general knowledge pattern with INDIRECT/INFERENTIAL evidentials.

\subsection{Summary of mutual knowledge and general knowledge}

The evidential category of mutual knowledge, broadly construed, covers any assertion which the speaker assumes is held in common with the addressee(s). In other words, the speaker shares epistemic authority for the assertion with others with whom common ground has been established. Current common ground may be limited to specific information shared by interlocutors in immediate social contexts, but it may extend to facts of a general nature widely diffused through the speech community. This latter type of mutual knowledge has been referred to as "general knowledge".

Well established facts of a general nature can be further categorized as gnomic, encyclopedic and traditional knowledge. Beyond these static modes of knowing, less widely established information continually spreads through social groups via interactive discourse and shared perceptual experiences, a process we refer to as "generalizing" knowledge. Speakers use individual knowledge evidentials with interlocutors who have not heard the latest bit of news or do not yet share the relevant idea. Mutual knowledge evidentials, on the other hand, are used with those who are becoming or are now part of the social group who share this knowledge. As the scope of the shared knowledge community expands, mutual knowledge of lasting significance may become more firmly conventionalized as general knowledge.

While some languages have a dedicated marker to convey general knowledge (e.g., Central Pomo and Mamaindê), Quechuan languages do not. Instead, each selects from the available set of evidentials the one that most closely conforms to the notion of general knowledge. We identified four different non-dedicated markers in four Quechuan varieties (Table 1). This lack of convergence in well developed evidential systems within the same family suggests that general knowledge is a late (or the last) evidential category to grammaticalize; see discussion in section 10.

Finally, many linguists consider general or common knowledge to be a canonical evidential mode of knowing (Aikhenvald 2004:126; Mithun 1999:181; Rooryck 2001:126; among others). As presented here, general knowledge itself is situated within the larger mutual knowledge evidential category, one in which the speaker shares epistemic authority for an assertion of fact not just with interlocutors but with all members of the speech community.

\section{Three Quechua evidential systems revisited}

We have seen that Quechuan languages provide excellent illustrations of some kinds of elaboration that may develop in an evidential system. The five-choice South Conchucos system was presented in section 6 and the six-choice Sihuas system in section 7 . The aim of this section is to compare the organization of these two evidential systems along with the three-choice system reported elsewhere in the language family.

Based on the examples in (1), the structure of the evidential system in Cusco Quechua can be represented as in Fig. 4. ${ }^{17}$ The two personal (firsthand) evidentials $-m i /-n$ and - chá,

\footnotetext{
17 Cusco Quechua is typically represented as having three evidential choices. However, the story is more complex than it first appears. See the discussion of Stage 4 at the end of section 10.
} 
contrast with the nonpersonal (secondhand) reportative $-s i$-s. The evidential contrast between personal and nonpersonal types is reported in many languages, motivated by the division "between reportativity on the one hand, and event perception, deduction, and inference on the other" (Hengeveld \& Hattnher, submitted:34).

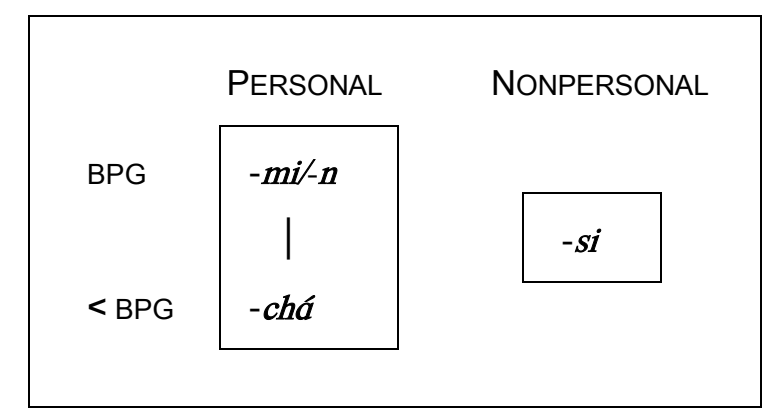

Fig. 4. THE THREE-CHOICE EVIDENTIAL SYSTEM IN CUSCO QUECHUA

As discussed in section 6, the evidential value of $-m i$ in Cusco is best expressed in terms of BPG "best possible grounds for making an assertion" (Faller 2002:130), because the speaker's evidence can range from direct experience to reasoning based on analogous experience. The evidential value of inferential -chá is also based on reasoning on the part of the speaker. These two evidentials differ in that $-m i$ presents the proposition as a fact, whereas -chá presents the proposition as less than $100 \%$ certain, ranging from conjecture to speculation. ${ }^{18}$ While -mi and -chá involve personal experience or reasoning on the part of the speaker, reportative -si simply indicates that "the speaker obtained information from others" (Faller 2002:22). In other words, BPG is not relevant to the meaning of reportative -si.

The evidential system in South Conchucos Quechua is represented in Fig. 5. This system shares with Cusco a high level contrast between personal and nonpersonal types. Within the personal section, both languages also encode a contrast between BPG and less than BPG. The added complexity in South Conchucos lies in the interpersonal dimension in which individual knowledge is distinguished from mutual knowledge, the evidential contrast introduced by -cha: and -cher. This entire set of four (inter)personal evidentials (-mi, -chi, -cha. and -cher) contrasts with the nonpersonal reportative (-shi).

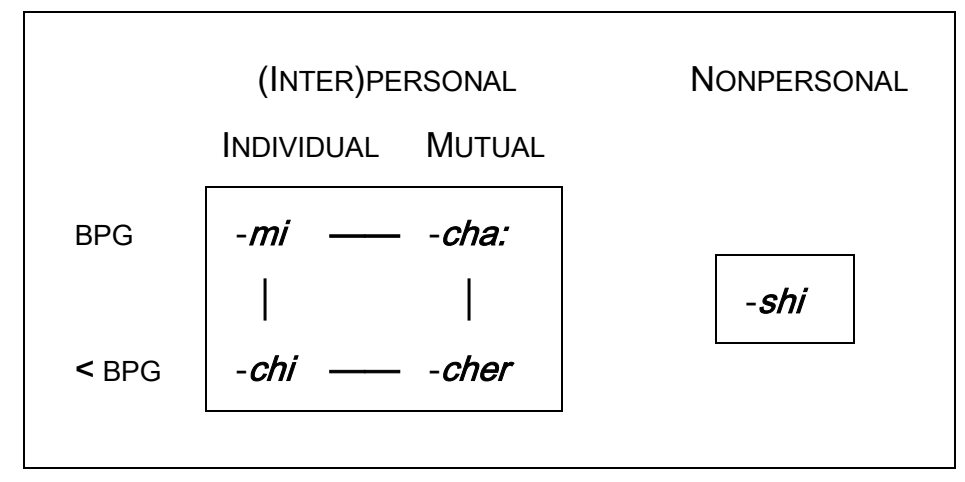

Fig. 5. THE FIVE-CHOICE EVIDENTIAL SYSTEM IN SOUTH CONCHUCOS QUECHUA

Finally, the evidential system of three contrastive pairs in Sihuas Quechua is represented in Fig. 6. This six-choice system can be compared to the three-choice Cusco system, with "mutual knowledge" counterparts to - $m i$ and -chri and a "generalized reported" counterpart to -shi.

18 This appraisal of -chá in Cusco Quechua applies equally well to the cognate marker -chra in Wanka Quechua which is "associated with assessments of probability, not factuality" (Floyd 1999:93). 


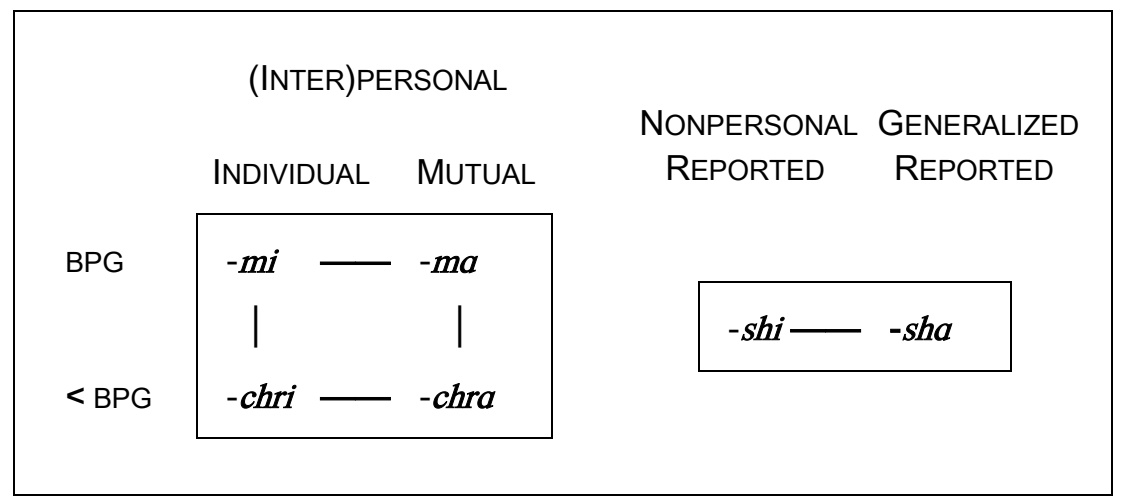

Fig. 6. THE SIX-CHOICE EVIDENTIAL SYSTEM IN SIHUAS QUECHUA

Both Sihuas and South Conchucos distinguish individual knowledge from mutual knowledge. The South Conchucos individual markers - $m i$, -chi and -shi essentially serve the same functions as their Sihuas counterparts -mi, -chri and -shi, respectively. The mutual knowledge markers, on the other hand, are similar in some ways, but differ in at least two respects.

First, South Conchucos -cha: and Sihuas -ma both confirm mutual knowledge. However, unlike Sihuas -ma, South Conchucos - cha: can appear at the end of a dialog in which speakers use multiple evidentials as they work toward and finally establish mutual knowledge. - cha: can also appear in isolation: a) to present knowledge that has been previously established as mutual, b) to mark mutual knowledge gained through shared experience, c) to frame individual knowledge as though it were mutual knowledge, and d) to convey general knowledge. In contrast, the role of Sihuas -ma is much narrower. It is generally part of an immediate response which simply confirms the joint evaluation of a proposition as true.

Second, the "generalizing knowledge" function of South Conchucos -cha: is similar to the role of Sihuas -sha which presents knowledge that has generalized and diffused through a speech community. These two evidentials differ in that the information source for Sihuas -sha is restricted to reported information, whereas South Conchucos -cha: does not have that restriction.

The forms and functions of the three Quechua evidential system types are summarized in Table 2. Line 1 (Cusco) represents the more generally attested three-choice evidential system. Line 2 (South Conchucos) and Line 3 (Sihuas) include cognates of the three-choice system together with the innovative interpersonal forms. The patterns in Table 2 suggest stages in the elaboration over time of the mutual knowledge evidential category. The next section considers the acquisition of these evidential contrasts in the intersubjective realm from a historical perspective.

Table 2. FORMS AND FUNCTIONS OF 3 QUECHUA EVIDENTIAL SYSTEMS

\begin{tabular}{ll|cc|cc|cc}
\hline & \multicolumn{2}{|c|}{ ASSERTION } & \multicolumn{2}{c|}{ CONJECTURE } & \multicolumn{2}{c}{ REPORTED } \\
& & INDIVIDUAL & MUTUAL & INDIVIDUAL & MUTUAL & NONPERSONAL GENERALIZED \\
\hline 3-CHOICE & Cusco & $-m i$ & - & $-c h a ́$ & - & $-s i$ & - \\
5-CHOICE & South Conchucos & $-m i$ & $-c h a:$ & $-c h i$ & $-c h e r$ & $-s h i$ & - \\
6-CHOICE & Sihuas & $-m i$ & $-m a$ & $-c h r i$ & $-c h r a$ & $-s h i$ & $-s h a$ \\
\hline
\end{tabular}




\section{Historical development}

The three Quechua evidential systems sketched in section 9 have three elements in common, derived from *-mi 'asserted information', *-chri/a 'conjecture' and *-shi 'reported information', respectively. The three-choice evidential system reported for many Quechuan languages, including Cusco (Southern Quechua), consists of enclitics that come from these three forms. ${ }^{19}$

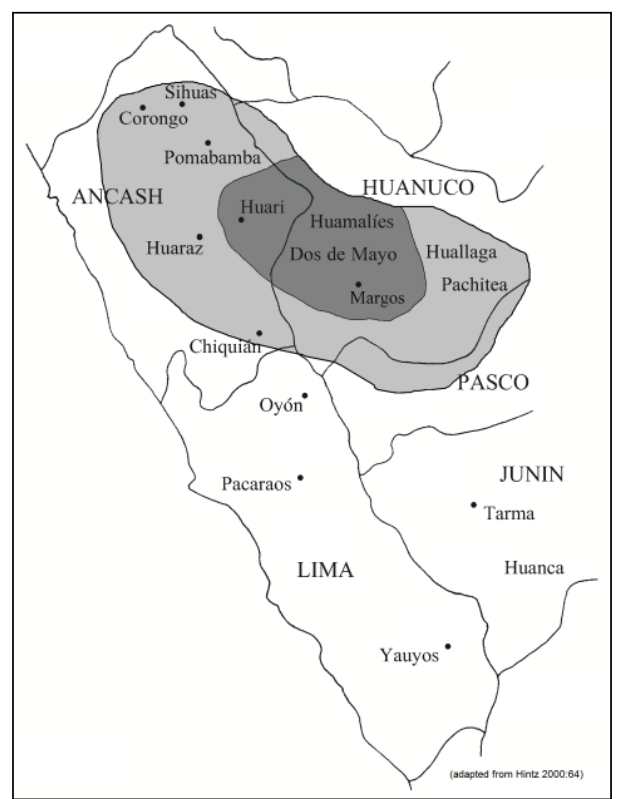

The five-choice evidential system in South Conchucos (Central Quechua) has two additional intersubjective forms, -cha: and -cher. Cognates of mutual knowledge -cha: (e.g., -chraq, -chaq, -chra:) point to the reconstruction of ${ }^{*}$-chraq. ${ }^{20}$ These evidentials derived from *-chraq are attested in the northern tier of Central Quechua, the modern varieties shown in the gray area in Fig. 7. They figure most prominently in the darker area labeled Huari (South Conchucos), Huamalíes, Dos de Mayo and Margos. The other form, mutual conjecture -cher, developed from the frequent cooccurrence of -chri followed by the affirmative particle ari. Pronunciation in South Conchucos varies between -cher and -chir. As in many varieties of Quechua, ari continues to function as a discourse particle and also has given rise to the affirmative enclitic $-r i{ }^{21}$

Fig. 7. CENTRAL PERU AREA WHERE EVIDENTIALS DERIVED FROM *-chraq ARE ATTESTED

The three intersubjective forms in the six-choice Sihuas (Central Quechua) evidential system (-ma, -chra and -sha) would have developed from the combination of the three original forms (-mi, -chri and -shi) plus ari, the same particle that gave rise to -cher in South Conchucos. ${ }^{22}$ Interesting parallels to the $a$-final forms in Sihuas are found elsewhere in the language family. ${ }^{23}$

19 The definitive identification of source material for ${ }^{*}-m i$, ${ }^{*}$-chri/a and ${ }^{*}-s h i$ is beyond reach with currently available data, though some forms are suggestive, e.g., ' *-shi< shimi 'mouth'.

20 Further evidence suggests that $t$-initial enclitics such as -taq, -tan and -ta: may be derived from *-chraq. These forms are attested throughout the language family as discourse markers denoting contrast, interrogation, exclamation, negation, etc.

21 Cognates of South Conchucos -cher in neighboring Quechua dialects include -cher in Huamalíes, -chiri in Huaylas, -chari in N. Conchucos, Huallaga and Margos, and -chrari in Corongo.

22 The very low frequency Sihuas evidential -chaq (from *-chraq) is probably not cognate with Sihuas -chra (from *-chri+ari), although a pre-proto relation between *-chraq and *-chri cannot be ruled out.

23 In contrast to nonproductive final $a$ in the Sihuas evidentials, an enclitic or particle of the form - $a$ : / $a:$ / - $a$ found in the southern region of Quechua I and further south into Quechua II attaches to a variety of evidential and non-evidential elements. For examples, see Adelaar (1986:82-4) on Pacaraos, Cerrón-Palomino (1976:234, 242-3) on Huanca, Soto Ruiz (1976:126-7) on Ayacucho and Wroughton (1996:65-6, 110, 144, 146) on Shausha Huanca. See also the Cusco form -má discussed in Stage 4 at the end of section 10. In addition to these final $a$ forms, other morphemes which combine with evidentials include -áw and -ár in Tarma (Adelaar 1977:300-1), -áw and -sik in Pacaraos (Adelaar 
These Quechuan languages suggest a sequence of stages in the development of the intersubjective component of evidential systems. In Stage 1 the evidential system is comprised of three choices: ASSERTION, CONJECTURE and REPORTED. This evidential system is attested in many modern Quechuan languages.

Table 3. StAGE 1: THREE-CHOICE EVIDENTIAL SYSTEM

\begin{tabular}{|c|c|c|}
\hline $\begin{array}{c}\text { ASSERTION } \\
\text { (SPEAKER) }\end{array}$ & $\begin{array}{c}\text { CONJECTURE } \\
\text { (SPEAKER) }\end{array}$ & $\begin{array}{c}\text { REPORTED } \\
\text { (nOn-SAP) }\end{array}$ \\
\hline
\end{tabular}

In Stage 2 ASSERTION and CONJECTURE split into two according to the distinction INDIVIDUAL versus MUTUAL, while REPORTED remains unified. As noted in section 9, the contrast between speech-act participant evidential types (ASSERTION and CONJECTURE) and non-SAP types (REPORTED) is well motivated. The five-choice evidential system in Table 4 is attested in South Conchucos Quechua. ${ }^{24}$

Table 4. STAge 2: FIVE-CHOICE EVIDENTIAL SYSTEM

\begin{tabular}{|c|c|c|}
\hline ASSERTION & CONJECTURE & $\begin{array}{c}\text { REPORTED } \\
\text { (non-SAP) }\end{array}$ \\
\hline $\begin{array}{c}\text { INDIVIDUAL MUTUAL } \\
\text { (SPEAKER) } \\
\text { ADDRESSEE) }\end{array}$ & $\begin{array}{c}\text { INDIVIDUAL MUTUAL } \\
\text { (SPEAKER) } \\
\text { (SPEAKER + } \\
\text { ADDRESSEE) }\end{array}$ & \\
\hline
\end{tabular}

In Stage 3 the category REPORTED splits into two according to the distinction NONPERSONAL and GENERALIZED, a category in which information is held in common by members of the speech community. The late development of a dedicated marker for the GENERALIZED category concords with the data presented in Table 1 in which Quechuan languages which lack a GENERAL or GENERALIZED evidential type recruit evidentials from other categories to express general knowledge. The six-choice evidential system in Table 5 is attested in Sihuas Quechua.

Table 5. STAGE 3: SIX-CHOICE EVIDENTIAL SYSTEM

\begin{tabular}{|c|c|c|c|c|c|}
\hline \multicolumn{2}{|c|}{ ASSERTION } & \multicolumn{2}{|c|}{ CONJECTURE } & \multicolumn{2}{|c|}{ REPORTED } \\
\hline $\begin{array}{l}\text { INDIVIDUAL } \\
\text { (SPEAKER) }\end{array}$ & $\begin{array}{l}\text { MUTUAL } \\
\text { (SPEAKER + } \\
\text { ADDRESSEE) }\end{array}$ & $\begin{array}{l}\text { INDIVIDUAL } \\
\text { (SPEAKER) }\end{array}$ & $\begin{array}{l}\text { MUTUAL } \\
\text { (SPEAKER + } \\
\text { ADDRESSEE) }\end{array}$ & $\begin{array}{l}\text { NONPERSONAL } \\
\text { (non-SAP) }\end{array}$ & $\begin{array}{l}\text { GENERALIZED } \\
\text { (SPEECH } \\
\text { COMMUNITY) }\end{array}$ \\
\hline
\end{tabular}

The elaboration of an intersubjective component within the evidential system is not the end of the story. A system that encodes many evidential distinctions may be susceptible to simplification over time. In Stage 4 certain markers fall into disuse by subsequent generations. However, particular forms may live on as remnants of the earlier system with meanings that can be traced back to a prior stage.

A closer examination of Cusco Quechua illuminates this process. Although three evidentials (-mi, -si and -ch $\hat{a})$ are currently attested, there is an additional marker -má which

1986:84-6) and -iki in Ayacucho (Soto Ruiz 1976:125). We hope the present paper will stimulate research on the semantics and pragmatics of these and other forms which appear to express intersubjective perspectives.

${ }^{24}$ Evidential systems with four or more choices, but without an intersubjective component, are presented by Aikhenvald (2004:51ff). 
Cusihuamán $r \quad$ efers to as "impressive...emphatic" (1976:243-4) and Faller glosses as "surprise" (2002:191). ${ }^{25}$ The $a$-final form -má is probably a remnant of an earlier system similar to the six-choice system in Sihuas (-mi vs. -ma, -shi vs. -sha, -chri vs. -chra). This scenario is further supported by the existence of the $a$-final form of the conjectural, that is, -chá instead of -chi. The other two evidential elements (-sha and -chri) are not attested in Cusco and presumably were lost. Alternatively, Cusco may have inherited only a subset of evidentials from the Central Quechua homeland. ${ }^{26}$

Summarizing, we have taken a brief tour of the history of two closely related five- and six-choice evidential systems against the backdrop of a more generally attested three-choice system. In each of the richer varieties, the evidential system acquired an intersubjective component, presumably via the functional pressures of interactive discourse. Many of these intersubjective evidentials (-ma, -sha, and -chra in Sihuas Quechua, -cher in South Conchucos Quechua) result from the amalgamation of existing forms with a reduced form of the affirmative particle *ari. The South Conchucos mutual knowledge marker -cha; , on the other hand, can be traced to the form *-chraq from a very early stage of the language.

\section{Conclusions}

We have examined Quechua evidential markers principally within the context of naturallyoccurring conversation. This approach led to the discovery of the grammatical expression of mutual knowledge, a category which has not received much attention in the literature on evidentiality. For speakers of South Conchucos Quechua, Sihuas Quechua and neighboring dialects in central Peru, the categories of individual versus mutual knowledge arise from the flow of everyday experience and provide a window into their intersubjective world, especially as they organize and combine elements of individual knowledge into more complex jointly constructed notions.

Specifically, the South Conchucos Quechua data show that knowledge is grammatically expressed not only by means of the contrast between personal and nonpersonal source of information (distinguished by direct - mi and conjectural -chi versus reportative -shi), and by fact versus conjecture (distinguished by -mi and -cha: versus -chi and -cher), but also within the interpersonal dimension of individual versus mutual knowledge (distinguished by $-m i$ versus -cha: and -chi versus - cher).

The nature of mutual knowledge marked by South Conchucos -cha: ranges from information established by consensus during a conversation (6), to shared experiences (9), to the latest news as it spreads through a speech community (23d), to well established ideas entrenched as general knowledge (11), (23a-c). Accordingly, information sources for the evidential category of mutual knowledge include the contributions of conversational participants, the beliefs and assumptions of the participants when interpreting shared experiences, and what members of the speech community can be expected to know about the world. Speakers use individual knowledge evidentials to introduce information and then use mutual knowledge evidentials once the fact has been established by consensus (10). In sum, mutual knowledge encompasses general knowledge-a canonical evidential category-plus the interpersonal types of knowledge shared between speakers in dynamic, interactive discourse.

25 The Cusco Quechua marker -má requires further analysis to determine its precise meaning. Assuming that -má retains an intersubjective function, a study of this marker would need to include spontaneous conversation as in the investigations of South Conchucos and Sihuas.

26 The reduction of the intersubjective component of the Cusco Quechua evidential system (with retention of the -má form) can be compared to the loss of inflectional case from Old Swedish to Modern Swedish (with retention of the -ar form) (cf. Norde 2002:46). In each case, the meaning of the remnant form can be traced to the meaning it had in a grammatical system that was robust at a prior stage in the language. 
The related mutual conjecture marker -cher-situated in the same paradigm as the other four South Conchucos evidentials-constitutes an appeal for validation and a call for consensus which can be confirmed with -cha:(6). The proposition remains unconfirmed when the conversation continues using evidentials other than -cha: In this way, South Conchucos speakers employ the full evidential set (-mi, -cha:, -chi, -cher, -shi) in the coconstruction of mutual knowledge which accumulates during the course of a conversation and is grammatically marked as such in subsequent speech. ${ }^{27}$

The six evidential enclitics in Sihuas Quechua grammatically encode individual versus mutual knowledge as well, but the evidential paradigm is elaborated as three contrastive pairs: - $m i$ versus - $m a$, -chri versus - chra, and -shi versus -sha. Personal information (-mi and $-c h r i)$ and nonpersonal reported information (-shi) are expressed in much the same way that South Conchucos employs the three cognate markers. However, the three innovative Sihuas evidentials - ma, -chra and -sha distinguish different types of mutual knowledge and have no exact counterparts in South Conchucos. Mutual direct -ma codes knowledge that the speaker and the addressee share, knowledge they have acquired firsthand and of which they are certain. It is used in confirming responses (14)-(15). Mutual conjecture -chra invites discussion on a matter the speaker is wondering about and which he thinks others would like to consider as well (17)-(18). Generalized reportative -sha codes reported information that has generalized among members of a social group (20)-(22).

The data suggest that the grammatical systems of five evidential markers in South Conchucos Quechua and six in Sihuas Quechua do not simply reflect knowledge as though it were a fixed or static entity, but rather speakers exploit these grammatical resources to linguistically co-construct knowledge about the world and about themselves through their discourse practices in social interaction. Building mutual knowledge by linguistically monitoring and co-constructing current common ground represents a promising direction in advancing our understanding of the intersubjective nature of evidentiality.

\section{References}

Author1. 2000.

Author1. 2006.

Author1. 2011.

Author1. 2014.

Author2. 2003.

Author2. 2007.

Adelaar, Willem F.H. 1986. Morfología del quechua de Pacaraos. [CILA Documento de Trabajo 53]. Lima.

Adelaar, Willem F.H. 1997. Los marcadores de validación y evidencialidad en quechua: ¿automatismo o elemento expresivo? Amerindia 22.3-13.

Aikhenvald, Alexandra Y. 2003. Evidentiality in Tariana. In A. Aikhenvald \& R.M.W. Dixon (eds.), Studies in Evidentiality, 131-64. Amsterdam: John Benjamins.

Aikhenvald, Alexandra Y. 2004. Evidentiality. Oxford: Oxford University Press.

Bergqvist, Henrik. 2012. Epistemic marking in Ika (Arwako). Studies in Language 36(1), 154-181.

Cerrón-Palomino, Rodolfo. 1976. Gramática quechua: Junín-Huanca. Lima: Ministerio de Educación and Instituto de Estudios Peruanos.

${ }^{27}$ Ethnographic studies have long recognized mutuality and consensus as fundamental values within traditional Quechua communities, as recently mentioned, e.g., by Howard (2002), Stobart (2002:102) and Zoomers (2006:1033). The grammatical marking of individual versus mutual knowledge reported here may be understood as the natural expression of these consensus values. Assuming that such values permeate many societies (see, e.g., Givón 2002:301 "societies of intimates"), grammatical consensus devices may be more common cross-linguistically than currently reported. 
Chafe, Wallace. 1970. Meaning and the structure of language. Chicago: University of Chicago Press.

Choi, Soonja. 1995. The development of epistemic sentence-final modal forms and functions in Korean children. In J. Bybee \& S Fleischman (eds.), Modality in grammar and discourse, 165-204. Amsterdam: John Benjamins.

Clark, Herbert H. 1996. Communities, commonalities, and communication. In J. Gumperz \& S. Levinson, Rethinking linguistic relativity, 324-55. Cambridge: Cambridge University Press.

Clark, Herbert H. \& Adrian Bangerter. 2004. Changing ideas about reference. In I. Noveck \& D. Sperber (eds.), Experimental Pragmatics, 25-49. Basingstoke: Palgrave Macmillan.

Clark, Herbert H. \& Susan E. Brennan. 1991. Grounding in communication. In L. Resnick, J. Levine \& S. Teasley (eds.), Perspectives on socially shared cognition, 127-49. Washington, DC: APA Books.

Clark, Herbert H. \& Edward F. Schaefer. 1989. Contributing to discourse. Cognitive Science 13, 259-94.

Cornillie, Bert. 2009. Evidentiality and epistemic modality: On the close relationship between two different categories. Functions of Language 16:1, 44-62.

Cusihuamán, Antonio. 1976. Gramática quechua: Cuzco-Collao. Lima: Ministerio de Educación and Instituto de Estudios Peruanos.

de Haan, Ferdinand. 2001. The place of inference within the evidential system. International Journal of American Linguistics 67.193-219.

Dickinson, Connie. 2000. Mirativity in Tsafiki, Studies in Language 24(2), 379-421.

Du Bois, John W. 2007. The Stance Triangle. In R. Englebretson (ed.), Stancetaking in discourse: Subjectivity, evaluation, interaction, 139-182. Amsterdam: John Benjamins.

Eberhard, David M. 2009. Mamaindê grammar: A Northern Nambikwara language and its cultural context. Utrecht: LOT.

Edwards, Derek. 1997. Discourse and cognition. London: Sage Publications.

Evans, Nicholas. 2007. View with a view: Towards a typology of multiple perspective. Proceedings of the Berkeley Linguistics Society 2005, 93-120.

Faller, Martina T. 2002. Semantics and pragmatics of evidentials in Cuzco Quechua. Ph.D. dissertation, Stanford University.

Floyd, Rick. 1999. The structure of evidential categories in Wanka Quechua. Dallas: Summer Institute of Linguistics \& University of Texas, Arlington.

Givón, Talmy. 2002. Bio-linguistics: The Santa Barbara Lectures. Amsterdam: John Benjamins.

Grice, Paul. 1975. Logic and conversation. In P. Cole \& J. Morgan (eds.), Syntax and semantics, 3: Speech acts, 41-58. New York: Academic Press.

Hengeveld, Kees \& Marize Mattos Dall'Aglio Hattnher (submitted). Four types of evidentiality in the native languages of Brazil.

Heritage, John. 2012. The epistemic engine: Sequence organization and territories of knowledge. Research on Language and Social Interaction 45:30-52.

Hill, Jane H. \& Judith T. Irvine. 1992. Introduction. In J. Hill \& J. Irvine (eds.), Responsibility and evidence in oral discourse, 1-23. Cambridge: Cambridge University Press.

Howard-Malverde, Rosaleen. 1990. The speaking of history: 'Willapaakushayki' or Quechua ways of telling the past. London: Institute of Latin American Studies.

Howard, Rosaleen. 2002. The Tragedia del fin de Atahuallpa as evidence of the colonisation of knowledge in the Andes. In H. Stobart \& R. Howard (eds.), Knowledge and learning in the Andes: Ethnographic perspectives, 17-39. Liverpool: Liverpool University Press.

Kamio, Akio. 1997. Territory of information. Amsterdam: John Benjamins.

Kroeker, Menno. 2001. A descriptive grammar of Nambikuara. International Journal of American Linguistics 67.1-87.

Landaburu, Jon. 2007. La modalisation du savoir en langue andoke (Amazonie Colombienne). In Z. Guentchéva \& J. Landaburu (eds.) L'Enonciation médiatisée II: Le traitement épistémologique de l'information: illustrations amérindiennes et caucasiennes, 23-47. Leuven: Peeters.

Landerman, Peter Nelson. 1991. Quechua dialects and their classification. Ph.D. dissertation, University of California, Los Angeles.

Lewis, David. 1969. Convention: A philosophical study. Cambridge: Harvard University Press. 
Lewis, M. Paul, Gary F. Simons \& Charles D. Fennig (eds.). 2013. Ethnologue: Languages of the World, Seventeenth edition. Dallas: SIL International. Online version: http://www.ethnologue.com.

Littell, Patrick, Lisa Matthewson \& Tyler Peterson. 2010. On the Semantics of Conjectural Questions. In T. Peterson \& U. Sauerland (eds.), Evidence from evidentials, 89-104. University of British Columbia Working Papers in Linguistics, Vol. 28. Vancouver, Canada.

Maslova, Elena. 2003. Evidentiality in Yukaghir. In A. Aikhenvald \& R.M.W. Dixon (eds.), Studies in Evidentiality, 219-35. Amsterdam: John Benjamins.

McCarthy, John. 1990. Formalizing common sense: Papers by John McCarthy. Norwood, NJ: Ablex.

Mithun, Marianne. 1999. The languages of native North America. Cambridge: Cambridge University Press.

Mushin, Ilana. 2001. Evidentiality and epistemological stance. Amsterdam: John Benjamins.

Norde, Muriel. 2002. The final stages of grammaticalization: Affixhood and beyond. In I. Wischer \& G. Diewald (eds.), New reflections on grammaticalization, 45-65. Amsterdam: John Benjamins.

Nuckolls, Janis. 2008. Deictic selves and others in Pastaza Quichua evidential usage, Anthropological Linguistics 50.1.67-89.

Nuyts, Jan. 2001. Subjectivity as an evidential dimension in epistemic modal expressions. Journal of Pragmatics 33.383-400.

Oswalt, Robert L. 1986. The evidential system of Kashaya. In W. Chafe \& J. Nichols (eds.), Evidentiality: The linguistic coding of epistemology, 29-45. Norwood, NJ: Ablex.

Parker, Gary J. 1976. Gramática quechua: Ancash-Huailas. Lima: Ministerio de Educación \& Instituto de Estudios Peruanos.

Rooryck, Johan. 2001. Evidentiality. Glot Internationa/ Vol. 5, No. 4.125-33.

Shiffer, Stephen R. 1972. Meaning. Oxford: Clarendon Press.

Snow, Charles T. 1973. Nominalizations in Ancash Quechua: I. Papers in Andean Linguistics, Vol. 2, No. 1, 5-129.

Soto Ruiz, Clodoaldo. 1976. Gramática quechua: Ayacucho-Chanca. Lima: Ministerio de Educación and Instituto de Estudios Peruanos.

Stalnaker, Robert C. 1978. Assertion. In P. Cole (ed.), Syntax and Semantics, v. 9 Pragmatics, 315-32. New York: Academic Press.

Stobart, Henry. 2002. Interlocking realms: Knowing music and musical knowing in the Bolivian Andes. In H. Stobart \& R. Howard (eds.), Knowledge and learning in the Andes: Ethnographic perspectives, 79-106. Liverpool: Liverpool University Press.

Torero, Alfredo. 1964. Los dialectos quechuas. Anales Cientificos de la Universidad Nacional Agraria 2.446-78.

Verhagen, Arie. 2005. Constructions of intersubjectivity: Discourse, syntax, and cognition. Amsterdam: John Benjamins.

Weber, David J. 1986. Information, perspective, profile, and patterns in Quechua. In W. Chafe \& J. Nichols (eds.), Evidentiality: The linguistic coding of epistemology, 137-55. Norwood, NJ: Ablex.

Weber, David J. 1989. A Grammar of Huallaga (Huánuco) Quechua. University of California Publications in Linguistics, Vol. 112. Berkeley: University of California Press.

Wroughton, John R. 1996. Gramática y textos del quechua Shausha Huanca. [Documento de Trabajo 30]. Yarinacocha, Peru: Ministerio de Educación and Instituto Lingüístico de Verano.

Zoomers, Annelies. 2006. Pro-indigenous reforms in Bolivia: Is there an Andean way to escape poverty? Development and Change 37.5.1023-46. 


\section{Acknowledgements}

This study was funded in part by National Science Foundation (USA) Grant BCS-0545334. The field investigation was sponsored by the Peruvian Ministry of Education and SIL International. We would like to thank Mary Bucholtz, Wallace Chafe, Soonja Choi, Herb Clark, Rosaleen Howard and Marianne Mithun for valuable conversations about the ideas presented here. Many thanks to the guest editors and reviewers for insightful comments and suggestions which improved the paper considerably. This line of research was presented at the Nature of Evidentiality Conference at Leiden University 2012, at SSILA 2007 and at the Congreso Internacional de Americanistas 2006 and benefited from interaction with conference participants. Special thanks go to South Conchucos Quechua speakers Edilberto Valenzuela, Reida Valenzuela, Elías Márquez and Lucila Santiago, and to Sihuas Quechua speakers Clever Encarnación, Diomides López, Edilberto Simeon and Tomás Lucero for graciously allowing us to participate in their "mutual knowledge" communities. 